\title{
Implementation of Electronic Signing Card (E-KTP) in Murung Raya District
}

\author{
Miranti, ${ }^{*}$ Setia Budhi, Jamal Uddin \\ Master Program of Government Science, Lambung Mangkurat University, Banjarmasin, Indonesia
}

DOI: $10.36348 /$ sijlcj.2020.v03i06.006

| Received: 29.05.2020 | Accepted: 06.06.2020 | Published: 12.06.2020

*Corresponding author: Miranti

\section{Abstract}

This study aims to describe and analyze how the implementation of the e-KTP program policy in Murung Raya Regency. The research approach uses qualitative research because the research problems studied are holistic, complex, dynamic, and full of meaning. The research method is field research which is a type of research that is oriented towards collecting empirical data in the field. Data collection techniques in this study were carried out by interview, some notes that were found in the field, and available documentation relating to this research. Data analysis is carried out using several key steps namely reducing data and presenting data to process the data that has been reduced in the form of a brief description that illustrates the findings of the study. The results of the implementation research of the Ministry of Home Affairs policy on the e-KTP program is to carry out the implementation of making electronic KTPs that were previously KTPs manually. The government's goal in making policies for implementing the e-KTP program is to create an orderly population administration and prevent negative impacts from the use of manual KTPs carried out by irresponsible parties that can harm the government and the community. From the results of the research analysis, it was concluded that the policy was not yet effective in its implementation in the field, partly because: human resource readiness in the face of change and innovation; facilities and infrastructure; and coordination and communication both between organizations (stakeholders) and between individuals.

Keywords: Implementation, Policy, Electronic Identity Card (e-KTP).

Copyright @ 2020: This is an open-access article distributed under the terms of the Creative Commons Attribution license which permits unrestricted use, distribution, and reproduction in any medium for non-commercial use (NonCommercial, or CC-BY-NC) provided the original author and source are credited.

\section{Preliminary}

On the one hand, the development of the world of science and technology has brought tremendous benefits to human life. Although negative impacts or weaknesses are arising from the progress of science and technology, this seems to be covered by the positive impact or benefit of the progress of science and technology. The development of technology cannot be avoided in this life, because technological progress goes according to the progress of science. The development of information and communication technology produces positive benefits for human life and provides many conveniences, such as the ease of obtaining information and the ease of transacting electronically [1]. The development of information and communication technology can also help humans in carrying out their activities, because all activities can be done quickly, cheaply, and precisely so that work productivity increases [2, 3]. The development of information and communication technology shows. The emergence of various types of activities based on this technology, such as in the world of government (e-government) which has programs such as population (e-KTP), education (e-learning), health (e-medicine, elaboratory), and others, all of which are electronicbased [4].

The government implements e-government aimed at realizing a democratic, transparent, clean, fair, accountable, responsible, responsive, effective, and efficient government free from the nuances of corruption, collusion, and nepotism (KKN) [5]. Egovernment utilizes advances in communication and information technology in various aspects of life, as well as for increasing competitiveness with other countries. As stated in Law No. 11 of 2008 concerning Electronic Information and Transactions. E-government implements an electronic-based government system to provide comfort, increase transparency, interact with the community, and increase public participation $[6,7]$.

Based on the explanation, one application of egovernment implementation in public services with the use of technology and information currently 
implemented in the field of government is the Electronic Resident Identity Card (e-KTP) [8, 9]. Indonesia with a large population requires valid and accurate population data, for that the government makes a policy program called e-KTP. KTP-el is one of the national programs that must be carried out by the government of each region in the territory of the Republic of Indonesia because the implementation of KTP-el is considered very relevant to the government's plan to create quality and technology-based public services to obtain more precise and accurate population data.

E-KTP is a program that has been created by the government through the Ministry of Home Affairs since 2006 but was only established and implemented in 2009, based on presidential laws and regulations. Such as in DKI Jakarta and Jembrana-Bali Regencies which are used as a pilot project for the application of KTP-el. DKI Jakarta has targeted all KTPs to have been equipped with fingerprint identities since 2009. E-KTP is a national KTP that has fulfilled all the provisions stipulated in Law No. 23 of 2006 which was revised by Law No. 24 of 2013 concerning Population Administration, Presidential Regulation No. 35 of 2010 concerning Amendments to Presidential Regulation No. 26 of 2009 concerning the Implementation of National Identification Number-based KTP (NIK) nationally (Source: Draft of Population Data Update Kab. Murung Raya; Disdukcapil; 2010).

The government makes e-KTP program policies, both for the community, nation, and state intended to create an orderly population administration. Besides, it is expected to avoid undesirable things, such as preventing and closing the opportunity for duplication of data or fake KTPs that have been misused by many irresponsible people and cause harm to the state and society. To support the realization of an accurate population database, especially concerning the required KTP population data that is identical to the data on potential population voters for the election (DP4), so that the permanent voter list (DPT) of the election which has often been problematic does not happen again.

With the existence of e-KTP, the community can support the improvement of state security through closed opportunities for multiple or fake KTPs where criminals including terrorists, illegal TKIs, and human traffickers often use these double IDs or fake IDs to falsify their identities so they are not identified authorities. In the period before the e-KTP program policy was established, actually in Indonesia, including Murung Raya Regency, it had already implemented a population document publishing service with a database-based and nationally connected computerized system called the Population Administration Information System (SIAK).
However, SIAK has not been equipped with data in the form of fingerprint recording and iris scans, so the opportunity to falsify data by an irresponsible person is easier. Besides that, not all of the districts/cities that have implemented SIAK are connected "online" to the center or there are still "offline" so that the data communication network between districts/cities is offline if there is a population migration that cannot be done systemically, and finally can cause duplication of data or multiple data and allow the issuance of fake ID cards. This article aims to describe how the implementation of e-KTP publishing in Murung Raya Regency, especially in terms of public services.

\section{RESEARCH METHODS}

The approach used in this research is qualitative to obtain an in-depth description of the eKTP program policy implementation process in Murung Raya Regency. In this approach, the researcher makes a complex picture, examines words, detailed reports from the respondents' views, and conducts a study of the situation experienced [10]. Nevertheless in this study, researchers did not find a quantitative approach, because it cannot be denied that statistical data were obtained in this study, resulting in a more comprehensive discussion [11]. This research belongs to the type of descriptive qualitative research intending to study intensively about the background of the problem situation and the content of an event that is taking place at this time, and environmental interactions of certain social units that are (given). Research subjects can be individuals, groups, institutions, or society. Descriptive qualitative research is an in-depth study of a particular social unit and the results of the study provide a broad and in-depth overview of a particular social unit [12].

In obtaining the required data and information, the following data collection techniques are used: 1) Literature study; namely data collection techniques by studying paper books, regulations, research journals and other written materials related to the research topic; 2) In-depth interviews; that is by using guidelines specifically designed for research so that research objectives can be achieved; 3) Documentation, recording the form of information either documents or records related to research problems [12].

Data analysis is the process of finding and organizing interviews and records obtained in the field and other materials that have been collected to formulate the results of what has been found relevant to the type of research that is qualitative research with descriptive methods, then the analysis technique used is qualitative. Data collected in the form of words and various sources are analyzed intensively. The data analysis technique is done by using qualitative data analysis techniques, by conducting an intensive analysis of data that has been obtained in the field in the form of 
words [13]. The steps that researchers use in analyzing data are following the opinions developed by Miles and Huberman. The analysis is carried out through the following procedures and stages:

1. Data reduction; is the selection of data and focusing on the data that is needed as the main data and also only complementary data. Data obtained from research sites or field data are outlined in the description or a complete and detailed report. The field report is reduced, summarized, selected key points, focused on the important things;

2. Presentation of data; intended to make it easier to see the overall picture or certain parts of the study;

3. Concluding; after presenting the data, the initial conclusions can be drawn. Conclusions are drawn during the study. Since the beginning of spaciousness and in the process of collecting data researchers have tried to carry out an analysis and look for the meaning of what was collected

So that the data or information obtained can be valid, then the data or information from one party is confirmed or verified by obtaining the same data from another source, for example from a second, third party, and so on using different methods. The aim is to compare data or information about the same thing but obtained from various parties or different sources, so that there is a guarantee of the level of data trust, to avoid the danger of subjectivity (Azwar, 2004). This method is often called Triangulation.

\section{RESULTS AND DISCUSSION}

The definition of policy implementation is "Implementation is the carrying out of basic policy decisions, usually incorporated in a statute but which can also take the form of important executive's orders or court decisions. Ideally, that decision identifies the problem (s) to be addressed, stipulates the objective (s) to be pursued, and, in a variety of ways, "structures" the implementation process" [14]. The implementation process is "Those actions by public or private individuals (or groups) that are directed at the achievement of objectives outlined in prior policy decisions" [15]. In short that to implement means to provide the means for carrying out (providing means to do something) [7].

Of the various models of public policy implementation, there is no best among models or theories, there is a choice of models that we must choose wisely according to the needs of its policies [16]. The Van Metter and Van Horn models are suitable as a basis for research because the variables in this theory are very clearly illustrated and measured [17]. The variables in this theory will be used to analyze and determine the success or failure of the e-KTP Program implementation in Murung Raya Regency. The Van Metter and Van Horn models were chosen because they are unique in studying how the implementation process was carried out and the variables in this theory, which will be used to measure the success or failure of the implementation of the e-KTP Program in Murung Raya Regency, has clear and detailed measurements. The strength of the Van Metter and Van Horn implementation model is that it sees implementation as a process of interaction of several implementing organizations. In the research on the implementation of the e-KTP Program in Murung Raya Regency, the implementing organization was the Murung Raya Regency Office.

Public policy does not appear by itself and has a specific purpose. Public policy to achieve the stated goals must go through several stages of implementation as well as what happens with the Electronic KTP Program (e-KTP). The next action resulting from the emergence of public policy is implemented. The Electronic KTP Program (e-KTP) is an elaboration of the Ministry of Home Affairs policy to create integrated population administration governance using the latest technological resources, which has strategic objectives is (www.e-ktp.com), that is:

1. Updating population data in an integrated manner to prevent all things that are distorting, such as dual population data and population data manipulation;

2. Become an integral, comprehensive, updatable population database that can be used to take care of all the needs for social service facilities, such as social security, economic security, and state budget subsidies;

3. Versatility for the benefit of economic activities such as banking (ATMs, e-banking) as well as instruments for electoral democracy activities, namely legalizing the list of prospective voters (voter's community).

Electronic KTP or e-KTP is a population document containing a security/control system both in terms of administration and information technology based on the national population database. The application of NIK-based KTP (Population Registration Number) is following Presidential Regulation Number 26 of 2009 concerning the Implementation of National Identification Number-Based KTP in conjunction with Presidential Regulation Number 35 of 2010 concerning Amendment to Perpres No. 26 of 2009.

The e-KTP program is motivated by a conventional KTP-making system in Indonesia that allows one to have more than one KTP. This is due to the absence of an integrated database that collects population data from all over Indonesia. This fact allows residents who want to cheat against the state by duplicating their KTP. Some of them are used for the following:

1. Avoiding taxes;

2. Makes it easy to make passports that cannot be made in all cities;

3. Securing corruption;

4. Concealing identity (for example by terrorists). 
To overcome this duplication while creating a multifunctional identity card, an e-KTP was initiated using biometric-based security. Authentication uses biometrics, namely verification and validation of the system through the introduction of physical characteristics of human behavior. There are many types of security in this way, including fingerprints, eye retina, DNA, face shape, and tooth shape. On e-KTP, fingerprints and retinal scanners are used. All fingerprints and retinal records of the population will be stored in AFIS (Automated Fingerprint Identification System) located in the data center in Jakarta. The purpose and benefits of using biometrics on e-KTP are as follows:

- Prevent counterfeiting and duplication;

- More economical and practical costs;

- If a card is lost, the person who finds the eKTP card of another person cannot use it because the biometric similarity is checked;

- The shape can be kept unchanged because fingerprint marks will return to their original shape even if the skin is scratched;

- Unique, there is no possibility even if a twin;

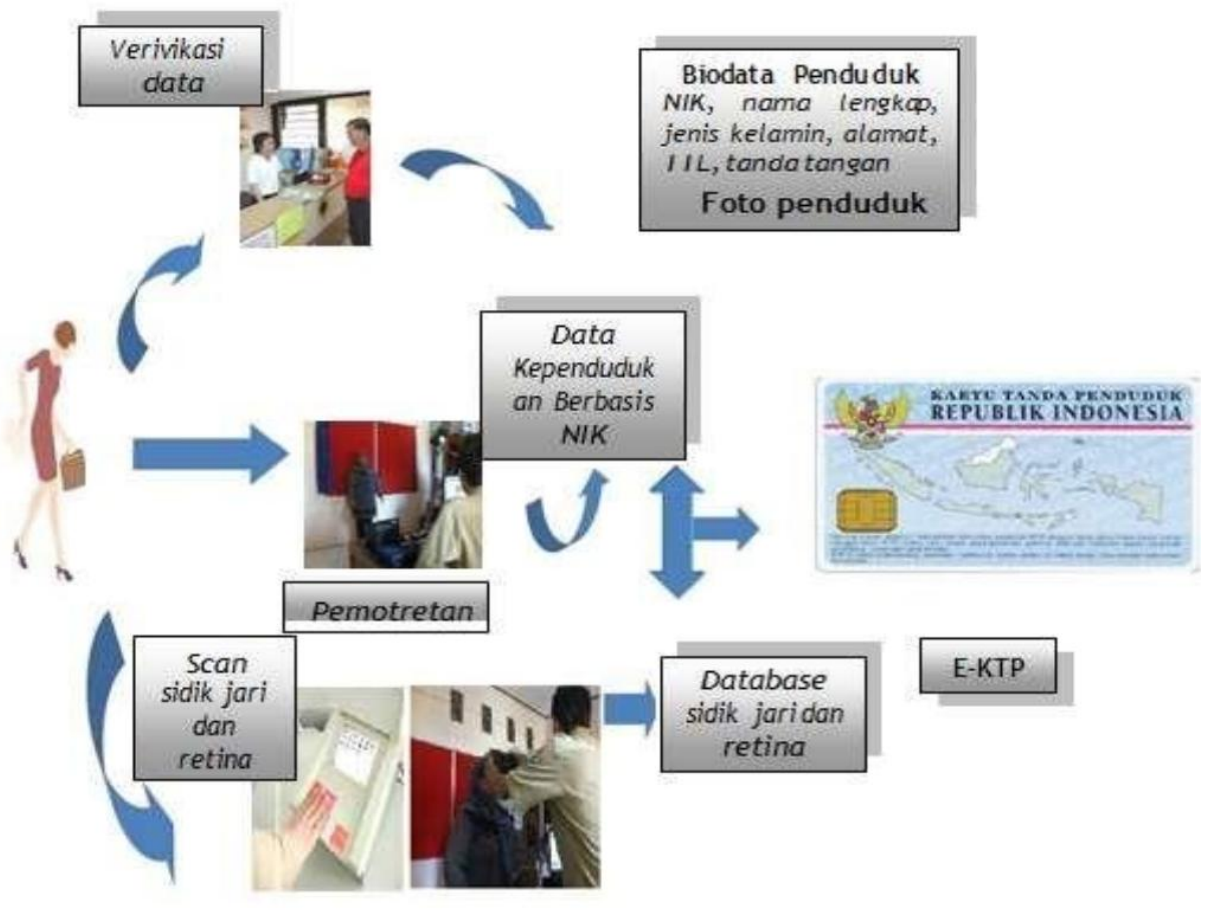

Sumber

This e-KTP program was carried out in stages in 497 Regencies / Cities in Indonesia. The first phase in 2016 was implemented in 197 districts/cities with a budget of Rp. $2.78 \mathrm{~T}$ sourced from the state budget and the remaining 300 regencies/cities were implemented eKTP in 2017 with a total budget of Rp. $3.46 \mathrm{~T}$ is sourced from the state budget. Palangkaraya City Included in the implementation of the First Phase which is targeted to be completed by the end of 2016. The process of implementing the e-KTP Program is carried out at the sub-district level in each sub-district office in each district/city. The following is a picture of the data recording process for e-KTP:

Based on the picture seen how the data security process for e-KTP. Residents (who have received invitation letters from the sub-district office) come to the sub-district office for the recording process according to the invitation schedule by bringing the invitation letter. Furthermore, residents are required to report to the officer for registration and given a queue number and then asked to queue. After being summoned, the residents were asked to verify their population data whether it was suitable or not. If there is something that is not appropriate, then immediately corrected. The residents were then photographed and then their fingerprint (ten fingers) were taken and their retinal eye records were taken. Finally, the residents concerned put their signatures on the signature pad provided. After all the processes have been undertaken, then the e-KTP recording process is complete and is just waiting for publication. The data (population demographics that have been verified and fingerprint and retina record data) are stored in a database and then sent through a data communication network to the Automated Fingerprint Identification System server in the Ministry of Home Affairs data center and a process of identifying one's oneness is identified. 
The results of identification of residents' fingerprints if a single identity, the data is returned to the Electronic ID card service point, and if multiple identities are clarified with the Electronic ID card service point. The data (population demographics that have been verified and fingerprint and retina record data) are stored in a database and then sent through a data communication network to the Automated Fingerprint Identification System server in the Ministry of Home Affairs data center and a process of identifying one's oneness is identified. The results of identification of residents' fingerprints if a single identity, the data is returned to the Electronic ID card service point, and if multiple identities are clarified with the Electronic ID card service point. The data (verified population biodata and fingerprint and retina record data) are stored in a database and then sent through a data communication network to the Automated Fingerprint Identification System server in the Ministry of Home Affairs data center and a process of identifying one's oneness is identified. The results of identification of residents' fingerprints if a single identity, the data is returned to the Electronic ID card service point, and if multiple identities are clarified with the Electronic ID card service point.

Then the personalization of the data that has been identified is carried out in the KTP Electronic blank. After personalizing the Electronic ID Card it is sent (distributed) to the Regency / City Dukcapil Office to be forwarded to the Electronic ID Card service. The officer at the Electronic KTP service receives the Electronic KTP and then provides it to the population by verifying through 1: 1 matching fingerprints.

The results of verification of the population's fingerprints, if the data are the same, the Electronic KTP is given to residents. If the data are not the same, then the Electronic KTP is not given to the population. If the data are not the same, the officer at the Electronic KTP service location returns the Electronic KTP to the Ministry of Home Affairs through the Regency / City Population and Civil Registry Service to be destroyed. Sources of funding for the e-KTP Program are charged to the Provincial / Municipal and Regency APBN and APBD. This is following Perpres No. 26 of 2009 concerning the Application of National Identity CardBased Resident Identity Number, Article 9 which reads:

a. Financing of hardware, software, NIK-based KTP blanks, and providing technical guidance on NIK-based KTP services by the Government as referred to in Article 2 paragraph (1) and paragraph (3), is charged to the State Budget.

b. Funding for the maintenance of hardware and software as referred to in Article 3 paragraph (3) and financing for the procurement and maintenance of supporting devices as referred to in Article 4 shall be borne by the Provincial and Regency / City Regional Revenue and Expenditure Budgets.
Programs and activities in the field of population administration are national strategic activities that require a large budget (Rp. 6, 24 T), but the results are also very large benefits for the community, nation, and state. Therefore, for the implementation to run effectively and efficiently with optimal results, there is a need for commitment from all parties, including the Government, Provincial Governments, District / City Governments, and the active role of all levels of society.

\section{CONCLUSION}

The implementation of the Population Identity Card Program (e-KTP) in Murung Raya Regency is concluded into six topics, as follows;

1. Policy Standards and Targets; Implementers of the e-KTP Program in Murung Raya Regency understand the operational and technical guidelines or SOP of the e-KTP program well. The implementation of the e-KTP Program in Murung Raya Regency is right on target;

2. Resources; Funding for the purchase of e-KTP devices and Technical Guidance for e-KTP Technical Service Operators is borne by the State Budget. Whereas funding for socialization and employee fees is borne by the Regional Budget so that funding for the implementation of the e-KTP Program is available and accommodated. The number of e-KTP technical service operators is sufficient as many as 6 (six) people to operate three sets of e-KTP devices;

3. Characteristics of the Implementing Agency; the bureaucratic structure in Murung Raya Regency is by the contents of the e-KTP Program policy. The implementation of the e-KTP Program does not interfere with the performance of other services in the District Office. Supervision conducted by the Camat to subordinates in the implementation of the e-KTP Program has been going well and is carried out routinely; the operator assigned is a civil servant who has a bachelor's degree and has been given the e-KTP Program Technical Guidance. In providing services, have prepared adequate and comfortable service rooms and waiting rooms for residents who are waiting in line. The time for implementing the e-KTP Program is until the end of April 2018;

4. Implementing Attitudes / Trends; Implementers of the e-KTP Program in Murung Raya Regency support the implementation of the e-KTP Program well and do not feel bothered by the implementation of this program;

5. Communication between Organizations and Implementation Activities; The communication developed by fellow implementers of the e-KTP Program in Murung Raya Regency is already good. Communication is built with family and open. There has never been a misunderstanding in communicating this policy. Communication between the Regency of Murung Raya and the 
Dukcapil Office went smoothly and periodically. Communication is built under office administrative procedures in the form of official letters. Communication with citizens is built through the socialization of the e-KTP Program. However, there are still many residents who do not know about the implementation of the e-KTP Program because the socialization is still very minimal and does not touch all levels of society in Murung Raya Regency;

6. Economic, Social and Political Conditions; The Economic Conditions of Murung Raya Regency have not been sufficient to support the implementation of the e-KTP Program in Murung Raya Regency due to limited funds for the socialization and payment of honorariums for eKTP technical service operators and the lack of funds for the purchase of generators. Communities in Murung Raya Regency have supported the implementation of the e-KTP Program, but the level of participation is still low. The political situation has supported the implementation of the e-KTP Program in Murung Raya Regency. Political Elite in the DPRD has provided support for the implementation of the e-KTP Program in Murung Raya Regency.

\section{REFERENCES}

1. Ndraha, T. (2003). Kybernology (Ilmu Pemerintahan Baru) 1. Jakarta: Rineka Cipta.

2. Batinggi, A. (1999). Manajerial Pelayanan Umum. Jakarta: Universitas Terbuka.

3. Dwiyanto, A. (2008). Reformasi Birokrasi Publik Indonesia. Yogyakarta: Gadjah Mada University Press.
4. Agus, D. (2005). Mewujudkan Good Governance Melalui Pelayanan Publik. Yogyakarta: Gajah Mada University Press.

5. Tjiptono, F. (1997). Total Quality Manajemen. Yogyakarta: Andi.

6. Thoha, M. (1996). Birokrasi dan Politik di Indonesia. . Jakarta: Raja Grafindo Persada.

7. Gaspersz, V. (1997). Manajemen Kualitas: Penerapan Konsep Vincent dalam Manajemen Bisnis Total. Jakarta: Gramedia Pustaka Utama.

8. Rivai, V. (2005). Manajemen Sumber Daya Manusia Untuk Perusahaan dari Teori ke Praktik. Jakarta: PT. Rajagrafindo Persada.

9. Moenir, A. (2008). Manajemen pelayanan Umum di Indonesia. Jakarta: Bina Aksara.

10. Kasiram. (2010). Metode Penelitian KualitatifKuantitatif. Malang: Uin Maliki Press.

11. Arikunto, S. (2003). Prosedur Penelitian, Suatu Praktek. Jakarta: Bina Aksara.

12. Sarman, M. (2004). Panduan Prosedur Penelitian dan Penulisan Tesis,. Banjarbaru. Kalsel: Program MSAP UNLAM.

13. Nasution. (2009). Metode Research (Penelitian Ilmiah). Jakarta: Bumi Aksara.

14. Parsons, W. (2005). Public Policy: Pengantar Teori dan Praktik Analisis Kebijakan; Edisi Pertama (Cetakan Pertama). Jakarta: PT. Prenada Media.

15. Keban, Y. T. (2004). Enam Dimensi Strategis Administrasi Publik: Konsep, Teori, dan Isu. Yogyakarta: Gava Media.

16. Kencana, I. (199). Ilmu Administrasi Publik. Jakarta: Rineka Cipta.

17. Bryson, J. M. (1999). Perencanaan Strategis Organisasi Sosial. Pustaka Pelajar: Yogyakarta. 